\title{
ANALISIS KESULITAN BELAJAR PESERTA DIDIK KELAS II PADA MATERI PENJUMLAHAN DAN PENGURANGAN
}

\author{
ANALYSIS OF LEARNING DIFFICULTY ON STUDENTS OF GRADE II \\ IN ADDITION AND SUBTRACTION SUBJECTS
}

\author{
Rohani*1, Heri Hadi Saputra $^{2}$, Awal Nur Kholifatur Rosydah ${ }^{3}$ \\ ${ }^{1,2,3}$ Pendidikan Sekolah Dasar, Fakultas Keguruan dan Ilmu Pendidikan, Universitas Mataram, \\ Indonesia \\ e-mail :rohani19981024@gmail.com ${ }^{1, *}$,heri_FKIP@unram.ac.id ${ }^{2}$,awal_rosydah@unram.co.id ${ }^{3}$
}

\begin{abstract}
ABSTRAK
Penelitian ini bertujuan untuk mengidentifikasi kesulitan belajar peserta didik pada materi penjumlahan dan pengurangan di kelas II Sekolah Dasar. Jenis penelitian ini adalah penelitian kualitatif dengan menggunakan metode deskriptif. Penelitian ini dilaksanakan di Sekolah Dasar Negeri 1 Suradadi pada bulan November 2020 dengan subjek penelitian 24 peserta didik kelas II. Instrumen dalam penelitian ini adalah tes, wawancara dan dokumentasi. Teknik analisis data yang digunakan yaitu analisis data model Iteraktif Analysis Miles and Huberman yang terdiri dari reduksi, penyajian data dan penarikan kesimpulan. Hasil penelitian menujukkan 1) terdapat peserta didik yang mengalami kesulitan belajar pada materi penjumlahan dan pengurangan; 2) kesulitan yang dialami oleh peserta didik kelas II disebabkan oleh beberapa faktor yaitu malas dan masih ada peserta didik yang belum bisa membaca sehingga tidak memahami maksud soal; 3) kesulitan yang dialami oleh peserta didik kelas II disebabkan karena kurangnya memahami konsep penjumalahan dan pengurangan bersusun panjang; 4) kesulitan belajar peserta didik disebabkan karena peserta didik tidak memahami konsep penjumlahan dan pengurangan teknik simpan dan teknik meminjam. Saran-saran yang dapat diberikan berdasarkan hasil penelitian yang telah dilakukan yaitu, bahwa pendampingan proses belajar penjumlahan dan pengurangan sangat perlu dilakukan oleh guru/orang tua dan penyajian soal sebaiknya dilakukan secara bertahap.
\end{abstract}

Kata Kunci: Kesulitan Belajar Peserta didik, Penjumlahan dan pengurangan.

\begin{abstract}
The aim of this study is to identify difficulty in learning addition and subtraction for students in grade II of Elementary School. This is a qualitative research using descriptive method. The study was conducted in Sekolah Dasar Negeri 1 Suradadi in November 2020 with 24 students of grade II as research subjects. Test, interview, and documentation were used as research instruments. While Miles Analysis and Huberman Analysis consisting of reduction, data presentation and conclusion formulation were used as data analysis technique. The results show that 1) there are students having difficulty in learning addition and subtraction subjects; 2) the difficulty faced by students of grad II is caused by several factors such as laziness and not yet able to read thus they cannot understand the questions; 3) students of grad II have not fully understood the concept of long stacked addition and subtraction; and 4) students have not fully understood the concept of saving and borrowing techniques in addition and subtraction. Recommendations obtained from this study are: 1) guidance provided by teachers/parents in learning addition and subtraction is required and 2) questions presentation should be conducted step by step.
\end{abstract}

Keywords: Students' Learning Difficulty, Addition and Subtraction. 


\section{PENDAHULUAN}

Pendidikan di Indonesia bertujuan untuk mencerdaskan kehidupan bangsa seperti yang tercantum dalam UUD 1945 alinea IV. Tujuan pendidikan disusun secara bertingkat, meliputi (a) tujuan pendidikan nasional; (b) tujuan institusional; (c) tujuan kurikuler; dan (d) tujuan pembelajaran (instruksional) [1]. Pembelajaran, khususnya dalam pendidikan formal masih menyisakan masalah. Salah satu permasalahan pembelajaran dalam pendidikan formal adalah masih rendahnya daya serap peserta didik [2]. Oleh sebab itu, proses pembelajaran adalah hal terpenting yang harus diperhatikan dalam belajar agar peserta didik tidak mengalami kesulitan belajar.

Kesulitan belajar merupakan ketidakmampuan peserta didik dalam menyelesaikan tugas-tugas yang diberikan oleh guru. Kesulitan belajar terjadi karena adanya gangguan secara nyata yang ada dalam diri peserta didik, baik itu gangguan neurologis, proses psikologis ataupun sebab-sebab yang lainnya, sehingga peserta didik mengalaminya di suatu kelas mendapatkan prestasi yang rendah [3]. Peserta didik yang mengalami kesulitan belajar memerlukan perhatian khusus untuk dapat meningkatkan prestasi akademiknya.

Kesulitan belajar dapat dialami oleh peserta didik pada berbagai tingkat pendidikan dan berbagai aspek muatan pelajaran, salah satunya muatan matematika. Peserta didik yang mengalami kesulitan belajar pada muatan matematika ditandai dengan sering melakukan kekeliruan dalam berhitung, kekeliruan dalam belajar geomertri, dan kekeliruan dalam menyelesaikan soal cerita [4]. Penyebab dari kesulitan belajar ini juga berbeda-beda setiap peserta didik, ditambah adanya perubahan kurikulum membuat peserta didik juga harus beradaptasi lagi dalam proses pembelajaran. Perubahan dari Kurikulum Tingkat Satuan Pendidikan (KTSP) ke kurikulum 2013 di tingkat Sekolah Dasar salah satunya berupa pembelajaran yang bersifat tematik. Pembelajaran tematik merupakan pembelajaran yang dirancang berdasarkan tema-tema tertentu dan ditinjau ditinjau dari berbagai mata pelajaran.

SD Negeri 1 Suradadi kecamatan Terara adalah salah satu sekolah yang telah menerapkan Kurikulum 2013. Dengan diberlakukannya Kurikulum 2013 ini guru harus menyampaikan pembelajaran sesuai dengan tema-tema yang sudah ditentukan, tidak terkecuali pada mata muatan Matematika. Berdasarkan hasil observasi terhadap guru kelas II SD Negeri 1 Suradadi, muatan matematika di sekolah tersebut dilaksanakan secara tematik, dengan mata pelajaran yang lainnya dalam satu tema. Pola pembelajaran seperti ini mengakibatkan, peserta didik merasa kesulitan dalam memahami materi, khususnya materi penjumlahan dan pengurangan.

Merujuk pada hasil penelitian yang sebelumnya pernah dilakukan, didapatkan bahwa hasil penelitian bahwa terdapat beberapa kesulitan yang dihadapi oleh peserta didik dalam mata pelajaran matematika di kelas IV karena kurangnya pemahaman mengenai simbol, penggunaan proses yang keliru dan kesulitan dalam perhitungan [5]. Penelitian serupa juga menyebutkan bahwa peserta didik terkadang mengabaikan lambang suatu bilangan, serta kurang memahami aturan dan prinsip dalam penyelesaian operasi hitung [6].

Disamping itu, penelitian lain juga menunjukkan bahwa terdapat beberapa kesulitan belajar yang dialami peserta didik antara lain kesulitan memahami dan mengenal simbol, kesulitan dalam membaca dan terdapat beberapa faktor yang mempengaruhi kesulitan belajar peserta didik [7]. Peserta didik kesulitan memahami konsep matematika, kesulitan dalam berhitung, kesulitan dalam memahami simbol dan kesulitan dalam memahami bahasa matematika pada soal [8].

Latar belakang tersebut, mendorong peneliti untuk melakukan penelitian tentang analisis kesulitan belajar peserta didik pada materi penjumlahan dan pengurangan di kelas II. Adapun tujuan penelitian ini adalah untuk mendeskripsikan kesulitan belajar yang dihadapi oleh peserta didik kelas II SDN 1 Suradadi pada mata pelajaran matematika materi penjumlahan dan pengurangan. 


\section{METODE PENELITIAN}

Pendekatan penelitian yang digunakan adalah pendekatan kualitatif dan jenis penelitian deskriptif. Penelitian dilaksanakan di SD Negeri 1 Suradadi Kecamatan Terara Kabupaten Lombok Timur. Waktu penelitian, dimulai pada bulan November 2020, bertepatan dengan semester ganjil tahun ajaran 2020/2021.

Teknik pengumpulan data menggunakan tes, wawancara, dan dokumentasi. Tes dilakukan kepada peserta didik kelas II SDN 1 Suradadi untuk mengetahui kesulitan-kesulitan peserta didik dalam mempelajari materi penjumlahan dan pengurangan. Wawancara mendalam dilakukan kepada peserta didik yang mengalami kesulitan dalam mengerjakan soal tes penjumlahan dan pengurangan. Wawancara juga dilakukan kepada guru kelas yang bersangkutan untuk memperoleh data dan gambaran akan kemampuan peserta didik. Dokumentasi dilakukan untuk mendokumentasikan nilai tes, serta proses peserta didik mengerjakan tes materi penjumlahan dan pengurangan.

Subjek pada penelitian ini yaitu peserta didik kelas II SDN 1 Suradadi. 24 peserta didik yang mengikuti tes dan terdapat hasil yang menunjukkan 4 peserta didik yang berhasil mendapatkan nilai diatas Kriteria Ketuntasan Minimal (KKM) dan terdapat 20 peserta didik yang mendapatkan nilai dibawah KKM. Penelitian dilanjutkan dengan wawancara kepada peserta didik yang memperoleh nilai tertinggi dan terendah.

Disamping itu, dilakukan juga wawancara kepada guru kelas II SDN 1 Suradadi. Kemudian dokumentasi juga digunakan dalam pengumpulan data berupa arsip data hasil belajar matematika kelas II SDN 1 Suradadi. Jenis kesalahan yang akan dianalisis meliputi kesulitan berhitung susun pendek, kesulitan berhitung susun panjang, serta kesulitan memahami soal. Analisis data dilakukan dengan cara reduksi data, penyajian data, dan penarikan kesimpulan.

\section{HASIL DAN PEMBAHASAN}

\section{Hasil Penelitian}

Berdasarkan hasil penelitian yang telah dilakukan, dapat diperoleh paparan data hasil penelitian. Paparan data ini sesuai dengan tujuan penelitian, yaitu mendeskripsikan kesulitan belajar yang dihadapi oleh peserta didik kelas II SDN 1 Suradadi khususnya pada Mata pelajaran Matematika materi penjumlahan dan pengurangan. Adapun data hasil penelitian tersebut adalah sebagai berikut.

Soal tes terkait penjumlahan dan pengurangan yang diberikan kepada peserta didik sebanyak sepuluh soal uraian. Pada soal nomor 1 dan 2, dimana soal nomor 1 dan 2 merupakan soal operasi hitung dengan cara bersusun pendek. Semua peserta didik kelas II berhasil menjawab dengan benar, menuliskan bentuk penjumlahan dan pengurangan dengan cara bersusun pendek. Dengan hasil tersebut, pada soal nomor 1 dan 2 peserta didik tidak mengalami kesulitan. Adapun penyataan salah satu peserta didik yang menyatakan bahwa untuk soal penjumlahan dan pengurangan dengan metode bersusun pendek merupakan soal yang sudah mereka pahami.

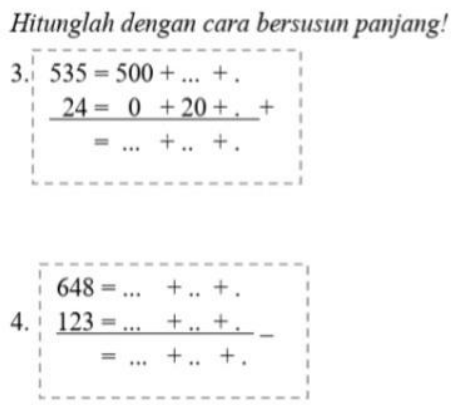

Gambar 1 Soal Tes Nomor 3 dan 4 
Pada soal nomor 3 dan 4 terdapat peserta didik yang mengalami kesulitan. Soal nomor 3 dan 4 ini merupakan soal operasi hitung dengan teknik bersusun panjang. Salah 1 peserta didik yaitu BA yang merupakan peserta didik yang berhasil memperoleh nilai diatas KKM, dapat menyelesaikan soal dengan benar dan tepat. BA berhasil menjawab dengan tepat, mulai dengan menuliskan bilangan yang merupakan ratusan, puluhan dan satuan, kemudian BA mampu menghitung hasil akhir dengan benar. Berbeda dengan NP dan 6 peserta didik lainnya yang tidak mampu menjawab soal tes nomor 3 dan 4, dan membiarkan lembar jawaban untuk soal nomor 3 dan 4 kosong.

Setelah ditelusuri lebih lanjut melalui wawancara, peneliti mendapatkan informasi bahwa NP dan beberapa temannya yang lain, mengalami kesulitan dalam menjawab soal tersebut karena belum memahami dan menurut mereka soal operasi hitung dengan teknik bersusun panjang ini merupakan soal yang sulit karena harus menuliskan angka ratusan, puluhan dan satuannya.

Kemudian untuk soal nomor 5, soal nomor 5 ini merupakan soal operasi penjumlahan dengan teknik menyimpan. Adapun pada soal nomor 5 TK salah satu peserta didik yang mendapatkan nilai diatas KKM berhasil menjawab soal dengan benar dan mampu menuliskan jawaban yang benar sesuai dengan soal. Soal nomor 5 ini peserta didik diminta untuk menyelesaikan penjumlahan dengan teknik simpan.

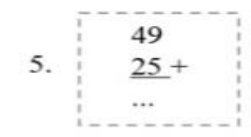

\section{Gambar 2 Soal Tes Nomor 5}

TK mampu menjawab dengan benar dan tepat menuliskan posisi bilangan yang harus di simpan. Sementara itu BAz menjawab dengan hasil yang salah, dimana pada jawaban BAz untuk penjumlahan dengan teknik simpan masih salah, BAz tidak menyimpan bilangan angka 1 dan langsung menuliskannya pada hasil akhir. Sehingga jawaban yang di tuliskan oleh BAz salah.

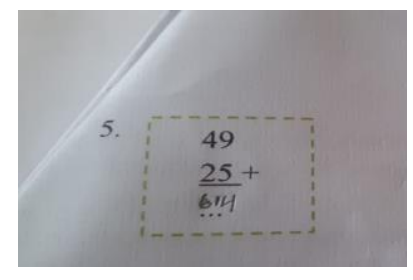

\section{Gambar 3 Hasil Tes BAz}

Soal nomor 6 juga merupakan soal penjumlahan dengan teknik menyimpan. Adapun bentuk soal nomor 6 yang disajikan adalah sebagai berikut.

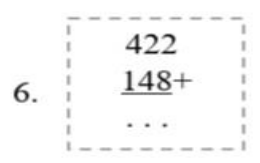

\section{Gambar 4 Soal Nomor 6}

Pada soal nomor 6 BR menjawab soal tes dengan benar dan menuliskan bilangan angka yang disimpan dengan benar. BR menjawab dan menuliskan jawaban dengan benar dan tepat. BR menuliskan angka yang disimpan pada posisis yang tepat dan berhasil menghitung hasil akhir dengan benar. Sementara itu BAz menjawab soal nomor 6 dengan kurang tepat, yaitu $\mathrm{BAz}$ tidak mampu melakukan penjumlahan teknik simpan dengan benar. Dimana BAz menuliskan bilangan angka yang harus disimpan, ditulis pada jawaban, sehingga hasil akhirnya salah. Adapun salah satu penyataan peserta didik yang mengatakan bahwa peserta didik 
mengalami kesulitan karena langsung menjawab saja, tanpa menghitung bilangan yang disimpan.

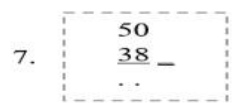

\section{Gambar 5 Soal Nomor 7}

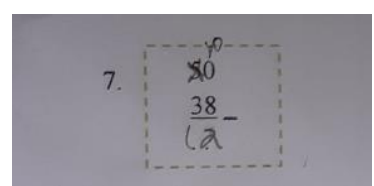

\section{Gambar 6 Hasil Tes BR}

Pada soal nomor 7 BR berhasil menjawab soal dengan benar dan mampu menuliskan bilangan mana yang dipinjam untuk menyelesaikan soal. BR mampu melakukan pengurangan dengan teknik meminjam, sehingga hasil akhirnya tepat. Sementara itu LMn menjawab soal nomor 7 dengan kurang tepat. LMn menuliskan bilangan yang di pinjam dengan benar akan tetapi tidak mengurangi nilai dari bilangan angka yang di pinjam dengan tepat. Sehingga LMn belum berhasil untuk menjawab soal dengan benar. Begitu pula dengan SR, salah satu peserta didik yang menjawab soal nomor 7 dengan kurang tepat. SR menjawab dengan kasus yang sama dengan LMn.

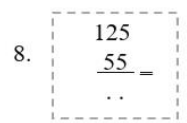

\section{Gambar 7 Soal Tes Nomor 8}

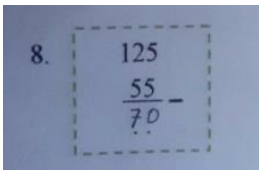

\section{Gambar 8 Hasil Tes BA}

Pada soal nomor 8 BA berhasil menjawab dengan benar dan mampu menyelesaikan dengan operasi pengurangan teknik meminjam. Begitupun dengan TK dan teman temannya yang lain, mereka mampu menyelesaikan soal dengan benar dan tepat. Untuk soal nomor 7 dan 8 merupakan soal dengan operasi pengurangan teknik meminjam. Adapun hasil wawancara yang menunjukkan bahwa peserta didik mengalami kesulitan karena peserta didik langsung menuliskan jawaban tanpa mengurangi angka yang di pinjam.

9. Amani dan Aina melihat bu Lala pulang dari pasar dan membawa buah segar. Amani dan Aina datang membantu bu Lala mengangkat buah tersebut. Amani membawa 8 buah jeruk dan Aina membawa 20 buah jeruk. Jumlah buah jeruk yang dibawa Amani dan Aina adalah..
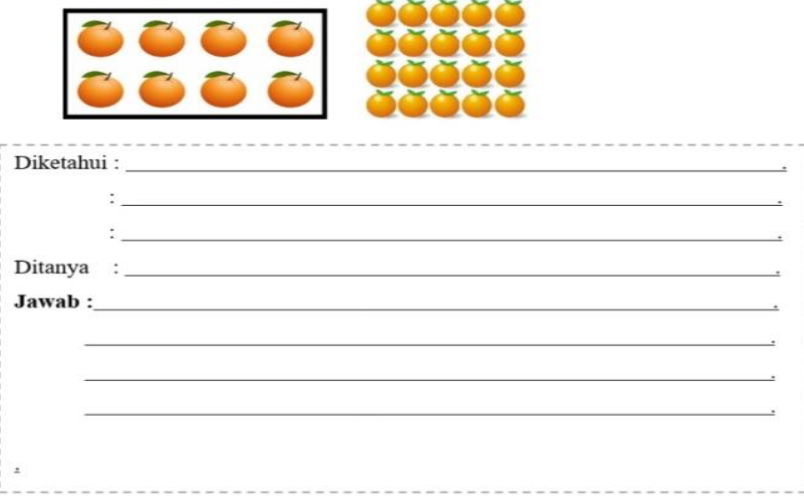

Gambar 9 Soal Nomor 9 
Selanjutnya pada soal nomor 9 , jenis soal pada nomor 9 adalah soal cerita memecahkan masalah matematika pada kehidupan sehari-hari. Adapun peserta didik yang berhasil menjawab soal nomor 9 ini adalah TK. TK berhasil menyelesaikan soal dan menjawab pertanyaan dengan benar dan tepat. TK berhasil menuliskan apa yang diketahui, yang ditanyakan dan menuliskan operasi hitung dengan benar. Akan tetapi banyak peserta didik yang tidak menuliskan langkah langkah cara menjawab soal nomor 9, dan langsung menuliskan jawabannya secara langsung, tanpa menuliskan apa yang diketahui dalam soal, tidak menuliskan apa yang ditanya dan hanya menjawab soal dengan cara menghitung jumlah buah jeruk melalui gambar saja. Setelah di lakukan wawnacara, terdapat informasi bahwa peserta didik menjawab soal dengan hanya menghitung jumlah jeruk pada soal saja tanpa harus menuliskan apa yang diketahui dan apa yang ditanyakan.

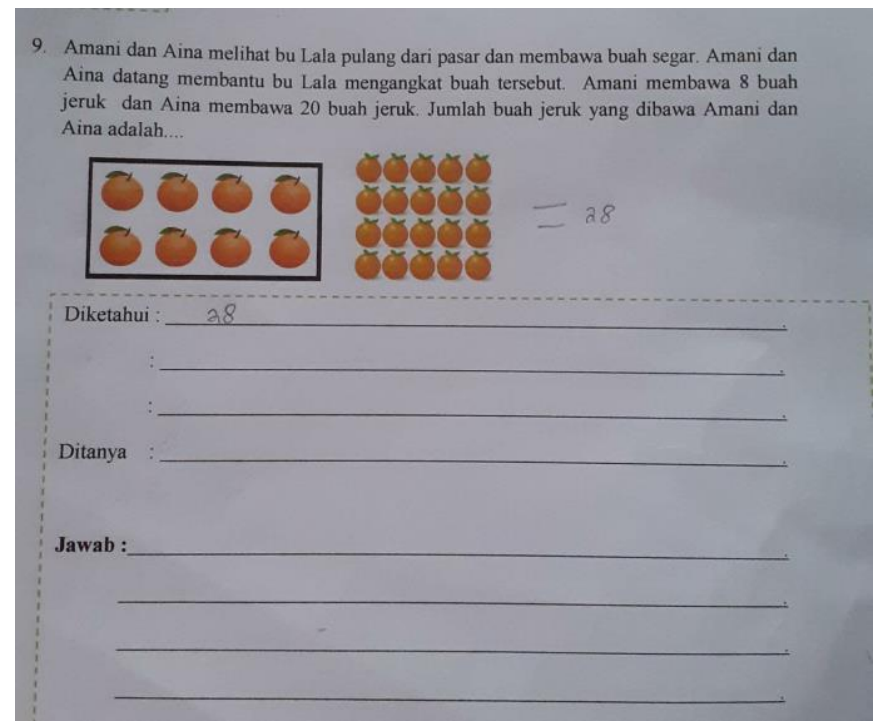

Gambar 10 Hasil Tes BAz

Berbeda dengan jawaban yang dituliskan oleh BAz dan 4 peserta didik lainnya menjawab secara langsung. BAz dan 4 peserta didik lainnya menuliskan jawaban yang benar untuk total jumlah jeruk, akan tetapi BAz menjawab sesuai dengan jumlah jeruk pada gambar. BAz tidak menuliskan apa saja yang diketahui, tidak menuliskan apa yang ditanya. Dan Baz langsung menjawab dan menuliskan jawabannya saja.Sementara itu NP dan 5 temannya yang lainnya tidak menjawab sama sekali, dan membirkan lembar jawabannya kosong.

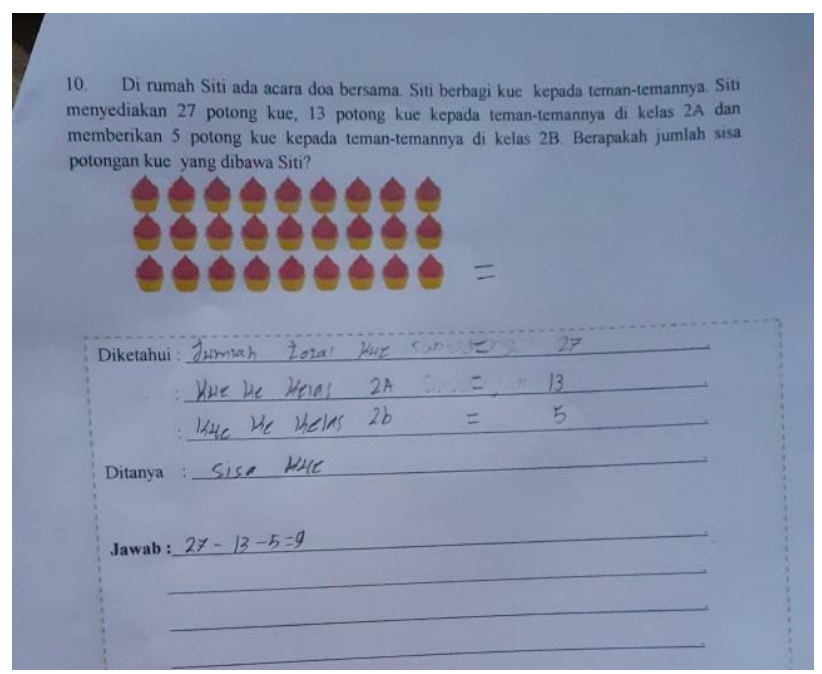

Gambar 11 Hasil Tes TK 
Selanjutnya untuk soal nomor 10 , peserta didik diminta untuk menyelesaikan soal cerita memcahkan permasalah pada kehidupan sehari-hari. Pada soal nomor 10 TK berhasil menjawab soal dengan benar dan tepat. TK berhasil menjawab soal mulai dari menuliskan apa yang diketahui, apa yang ditanyakan dan hasil akhir yang tepat. TK mampu menyelesaikan soal cerita dengan benar dan tepat. Sementara itu 23 peserta didik lainnya tidak mampu menyelesaikan soal nomor 10 .

Berdasarkan hasil tes diperoleh rata-rata hasil akhir peserta didik yaitu 62,5 dimana diketahui nilai tersebut dibawah KKM (Kriteria Ketuntasan Minimal) Matematika yaitu 75. Dari 24 peserta didik yang mengikuti tes hanya 4 orang peserta didik yang mencapai hasil diatas KKM sesuai dengan mata pelajaran Matematika. Nilai tertinggi perolehan tes yaitu 90 dan nilai terendah yaitu 40 .

Selain hasil tes, dilakukan wawancara terhadap 4 peserta didik kelas II SDN 1 Suradadi yang telah mengerjakan soal tes yang telah diberikan oleh peneliti dan memperoleh nilai diatas KKM, dibawah rata-rata dan dibawah KKM. Diataranya yaitu TK, BQ, LMn dan NS. Dari hasil wawancara diketahui bahwa TK, BQ, LMn dan NS paham apa itu penjumlahan dan pengurangan, dan mereka semua menyukai pelajaran matematika. Kemudian sikap yang mereka tunjukkan saat pelajaran Matematika juga sangatlah baik dan mengikuti pelajaran dengan lancar. Dari hasil wawancara yang telah dilakukan terdapat informasi bahwa dalam pembelajaran TK sangat fokus saat pembelajaran berlangsung begitupun dengan BQ dan NS. Sedangkan LMn masih kurang fokus, masih terkecoh dan bermain bersama temannya yang lain.

\section{Pembahasan}

Tes berupa 10 soal uraian penjumlahan dan pengurangan yang diberikan kepada 24 peserta didik kelas II SDN 1 Suradadi. Tes dikelompokkan menjadi tiga bentuk, yaitu soal tes dengan cara bersusun pendek (bersusun pendek dengan cara meminjam, dan bersusun pendek menyimpan), bersusun panjang dan soal cerita. Soal bentuk pertama berupa soal tes bersusun pendek, dengan teknik biasa (tanpa meminjam dan menyimpan). Jenis soal ini berjumlah 2 soal yaitu pada soal nomor 1 dan 2. Selanjutnya soal operasi hitung dengan teknik bersusun panjang sejumlah 2 soal yaitu soal nomor 3 dan 4, kemudian soal bersusun pendek dengan teknik menyimpan di soal nomor 5 dan 6 . Serta soal bersusun pendek dengan teknik meminjam pada soal nomor 7 dan 8. Selanjutnya soal bentuk ketiga berupa pemecahan permasalahan matematika pada kehidupan sehari-hari pada soal nomor 9 dan 10.

Pada soal nomor 1 dan 2 peserta didik kelas II SDN 1 Suradadi berhasil menjawab dengan benar dan tepat. Peserta didik sudah bisa membedakan simbol-simbol yang ada pada matematika diantaranya simbol Penjumlahan (+), pengurangan (-), dan sama dengan (=). Oleh sebab itu, untuk soal nomor 1 dan 2 ini berhasil dijawab oleh semua peserta didik dengan benar dan tepat. Kelemahan peserta didik dalam memahami symbol-simbol dapat mengakibatkan kesulitan belajar matematika [9]. Akan tetapi peserta didik, berhasil menuliskan dan menghitung jawaban dengan benar, sehingga dapat dikatakan bahwa peserta didik tidak mengalami kesulitan pada soal nomor 1 dan 2 .

Selanjutnya soal nomor 3 dan 4 banyak peserta didik yang mengalami kesulitan menjawab soal tersebut. Pada soal nomor 3 dan 4 merupakan soal operasi hitung dengan teknik bersusun panjang. Banyak peserta didik yang menjawab soal dengan hasil akhir yang salah dan bahkan ada yang tidak menjawab sama sekali. Kesulitan belajar peserta didik terjadi karena peserta didik tidak memahami maksud soal penjumlahan bersusun panjang dan mengalami kesulitan dalam memisahkan bilangan ratusan, puluhan dan satuan [7]. Banyak jawaban peserta didik dari hasil tes menunjukkan bahwa peserta didik kebingungan dalam menuliskan angkaangka yang harus di tulis padaa kolom jawaban yang disediakan. Kesulitan belajar matematika peserta didik dalam menentukan tempat dan posisi angka yaitu puluhan dan ratusan [10]. Adapun hasil wawancara yang dilakukan kepada salah satu peserta didik yang mendapatkan nilai di bawah KKM. Terdapat pernyataan yang bahwa peserta didik tidak mengerti maksud soal dan tidak bisa menguraikan ratusan, puluhan dan satuan pada soal. 
Kesulitan belajar peserta didik terlihat pada saat menjawab soal nomor 5, 6, 7 dan 8, dimana pada soal nomor 5,6, 7 dan 8 ini merupakan soal operasi hitung bersusun pendek dengan teknik menyimpan dan meminjam. Adapun kesulitan yang dihadapi oleh peserta didik diantaranya adalah menuliskan hasil akhir yang kurang tepat. Kesulitan dalam perhitungan biasanya terjadi karena peserta didik kurang teliti dalam mengerjakan soal yang diberikan [11]. Banyak peserta didik yang menuliskan langsung angka yang seharusnya di simpan. Begitupun dengan soal pengurangan dengan teknik meminjam. Peserta didik menuliskan jawaban secara langsung tanpa mengurangi angka yang di pinjam. Kesulitan belajar peserta didik karena tdak teliti ketika menghitung jawaban dan mengalami kekeliriuan dalam menghitung [12]. Peserta didik mengalami kesulitan dalam meghitung soal dan berdampak pada akhir jawaban yang otomatis salah [5].

Adapun hasil wawancara dengan salah satu peserta didik yang mendapatkan nilai di bawah KKM. LMn mengatakan paham apa itu operasi penjumlahan dan pengurangan teknik menyimpan dan meminjam, akan tetapi untuk hasil akhir jawabannya kurang tepat, karena kurang memperhatikan soal dan jawaban yang dituliskan. Kesulitan belajar peserta didik ditunjukkan dengan terdapat kesalahan umum yang dilakukan oleh peserta didik dalam menyelesaikan tugas-tugasnya dalam bidang studi matematika, salah satunya adalah tulisan yang tidak terbaca dan perhitungan yang salah [8].

Selanjutnya untuk soal nomor 9 dan 10 merupakan soal cerita memecahkan permasalahan kehidupan sehari-hari. Soal tes nomor 9 dan 10 ini hanya berhasil dijawab dengan tepat, lengkap dan benar oleh 2 peserta didik dari 24 peserta didik yang mengerjakan soal tes. Peserta didik mengalami kesulitan dalam menyelesaikan soal cerita karena tidak memahami maksud dari soal dan ada peserta didik yang belum terlalu lancar dalam membaca. Peserta didik tidak dapat menyelesaikan soal cerita karena belum bisa membaca, dan membuatnya tidak dapat memahami maksud soal yang disajikan. Sejalan dengan hasil wawancara dengaan peserta didik tersebut, hasil wawancara dengan guru kelas peserta didik kelas II yang menyatakan bahwa ada dari sebagian peserta didik yang maasih belum terlalu lancar dalam membaca.

Kesulitan belajar peserta didik pada soal cerita terjadi karena peserta didik kurang mampu memahami maksud dari soal dan kebingungan saat menentukan operasi hitung yang akan digunakan [13]. Pada peserta didik usia sekolah dasar, perkembangan konsep numerik, penalaran logis, dan membaca serta memahami teks menjadi kesulitan yang kerap muncul dalam pelajaran matematika [14]. Penelitian terdahulu juga menegaskan bahwa kemampuan memahami teks bacaan, dipengaruhi oleh kemampuan peserta didik dalam membaca [15]. Oleh sebab itu, kemampuan membaca peserta didik harus dikembangkan terlebih dahulu, agar peserta didik dapat memahami soal cerita yang disajikan.

Dalam menyelesaikan soal cerita peserta didik harusnya menuliskan apa yang diketahui dalam soal, menuliskan apa yang di tanyakan dan menuliskan jawabannya dengan pas. Kesalahan yang dilakukan oleh peserta didik dalam menyelesaikan soal cerita adalah tidak menuliskan apa yang diketahui dan yang ditanyakan [16]. Peserta didik banyak yang tidak menjawab dengan benar karena tidak menuliskan apa yang ketahui, yang ditanyakan dan jawbannya. Kesulitan belajar peserta didik sekolah dasar dalam menyelesaikan soal bentuk cerita yaitu bukan hanya kesulitan dalam membaca dan kesulitan memahami soal, tetapi juga kesulitan transformasi, kesulitan keterampilan proses, kesulitan penulisan jawaban [16]. Pada umumnya peserta didik menyalin kalimat yang tercantum pada soal dan menuliskan pada kolom jawaban yang disediakan. Selain itu peserta didik juga peserta didik terbiasa menuliskan dan menyelesaikan jawaban tanpa menuliskan bagian yang diketahui dan ditanyakan.

Berdasarkan triangulasi teknik dan triangulasi sumber, peserta didik kelas II SDN 1 Suradadi mengalami kesulitan belajar. Banyak peserta didik yang menyukai pelajaran matematika, akan tetapi tidak mau mengikuti les jam tambahan mata pelajaran matematika, kemudian peserta didik kelas II ini merupakan peserta didik yang belajar dirumah jika ada tugas tambahan seperti PR saja. Tidak memiliki niat belajar lanjutan meski tidak ada tugas tambahan. Berdasarkan hasil wawancara dengan alah satu orang terdekat peserta didik (Kakak), di temukan informasi bahwa, peserta didik kelas II ini memiliki dukungan yang cukup besar dari 
JurnalIImiah KONTEKSTUAL, Volume.2, No. 02, Februari 2021, pp. 17-26

keluarganya untuk melakukan pembelajaran lanjutan dirumahnya masing-masing, akan tetapi peserta didik yang lebih memilih bermain dari pada melanjutkan belajar dirumah.

Aktivitas belajar bagi setiap individu memiliki hambatan-hambatan tertentu sehingga berdampak pada proses pembelajaran, dan proses pembelajaran tidak selamanya berlangsung secara wajar [17]. Mereka meyukai pelajaran matematika materi penjumlahan dan pengurangan, dengan metode mengajar guru kelasnya yaitu ceramah, metode mengajar tanya jawab dan model pembelajaran realistik. Jika TK dan teman-temannya merasa kesulitan dalam memahami pelajaran dan menyelesaikan tugas, mereka bertanya kepada guru kelas dan meminta untuk mengulangi materi tersebut. Kemudian peserta didik peserta didik kelas II SDN 1 Suradadi sudah bisa membedakan simbol-simbol pada matematika, akan tetapi masih banyak yang belum bisa menyelesaikan penjumlahan dan pengurangan dengan teknik bersusun panjang dan soal cerita.

\section{SIMPULAN}

Berdasarkan penelitian terkait kesulitan belajar matematika penjumlahan dan pengurangan yang dihadapi oleh peserta didik kelas II SDN 1 Suradadi Kecamatan Terara, Kabupaten Lombok Timur dapat ditulis kesimpulan 1) terdapat peserta didik yang mengalami kesulitan belajar pada materi penjumlahan dan pengurangan; 2) kesulitan yang dialami oleh peserta didik kelas II disebabkan oleh beberapa faktor yaitu malas dan masih ada peserta didik yang belum bisa membaca sehingga tidak memahami maksud soal; 3) kesulitan yang dialami oleh peserta didik kelas II disebabkan karena kurangnya memahami konsep penjumalahan dan pengurangan bersusun panjang; 4) kesulitan belajar peserta didik disebabkan karena peserta didik tidak memahami konsep penjumlahan dan pengurangan teknik simpan dan teknik meminjam.

Saran-saran yang dapat diberikan berdasarkan hasil penelitian yang telah dilakukan yaitu, bahwa pendampingan proses belajar penjumlahan dan pengurangan sangat perlu dilakukan oleh guru/orang tua. Di samping itu, pemberian soal secara bertahap berdasarkan tingkat kesulitannya sangat perlu dilakukan kepada peserta didik secara teratur sebagai ajang latihan agar peserta didik terampil mengerjakan soal penjumlahan dan pengurangan.

\section{DAFTAR PUSTAKA}

[1] O. Hamalik, "Kurikulum dan Pembelajaran.” Bumi Aksara, Jakarta, 2014.

[2] Trianto, Mengembangkan Model Pembelajaran Tematik. Jakarta: Prestasi Pustakarta, 2010.

[3] E. M. Yeni, "Kesulitan Belajar Matematika Di Sekolah Dasar," Jurnal Pendidikan Dasar, vol. 2, no. 2, pp. 1-10, 2015, [Online]. Available: http://jfkip.umuslim.ac.id/index.php/jupendas/article/view/231.

[4] M. A. Syafiudin, A. Hartoyo, and A. Nursangaji, "Kesulitan siswa menyelesaikan soal mengenai jarak dalam bangun ruang berdasarkan model kesulitan newman," Jurnal Pendidikan dan Pembelajaran Khatulistiwa, vol. 7, no. 10, pp. 1-11, 2018, [Online]. Available: https://jurnal.untan.ac.id/index.php/jpdpb/article/view/29036.

[5] D. Faizah, "Analisis Kesulitan Belajar Siswa Pada Mata Pelajaran Matematika di MI AlMa'rifatul Islamiyah Dasan Agung Mataram," Universitas Islam Negeri Mataram, 2018.

[6] A. N. K. Rosyidah, M. A. Maulyda, and I. Oktaviyanti, "Miskonsepsi Matematika Mahasiswa PGSD Pada Penyelesaian Operasi Hitung Bilangan Bulat," Jurnal Ilmiah KONTEKSTUAL, vol. 2, no. 01, pp. 15-21, 2020, [Online]. Available: http://jurnal.umus.ac.id/index.php/kontekstual/article/view/244.

[7] M. Y. D. Muntadiharoh, "Analisis Kesulitan Belajar Siswa Kelas II Pada Materi Penjumlahan Di Madrasah Ibtidaiyah Negeri 4 Tulungagung," Universitas Islam Negeri 
Maulana Malik Ibrahim Malang, 2017.

[8] Murzani, "Analisis Kesulitan Belajar Siswa Pada Mata Pelajaran Matematika Di Kelas IV SDN 9 Masbagik Utara Tahun Pelajaran 2017/2018," Universitas Mataram, 2018.

[9] U. Mabruroh, D. Sunarsih, and A. Mumpuni, "Analisis Kesulitan Belajar Muatan Matematika Kelas IV SD Tahfidzul Qur'an Darul Abror," Jurnal Ilmiah KONTEKSTUAL, vol. 2, no. 01, pp. 58-68, 2020, [Online]. Available: http://jurnal.umus.ac.id/index.php/kontekstual/article/view/250.

[10] D. Selvianiresa, "Kesulitan Siswa Sekolah Dasar Pada Materi Nilai Tempat Mata Pelajaran Matematika Di Kelas I SD," Pendas : Jurnal Ilmiah Pendidikan Dasar, vol. 2, no. $1, \quad$ p. $65, \quad 2017, \quad$ [Online]. Available: https://journal.unpas.ac.id/index.php/pendas/article/view/451.

[11] N. Amallia and E. Unaenah, "Analisis Kesulitan Belajar Matematika Pada Siswa Kelas III Sekolah Dasar," Attadib Journal Of Elementary Education, vol. 3, no. 2, pp. 123133, 2018, [Online]. Available: https://www.jurnalfaiuikabogor.org/index.php/attadib/article/view/414.

[12] T. Runtukahu and S. Kandou, Pembelajaran matematika dasar bagi anak berkesulitan belajar. Yogyakarta, 2014.

[13] D. R. Utari, M. Y. S. Wardana, and A. T. Damayani, "Analisis Kesulitan Belajar Matematika dalam Menyelesaikan Soal Cerita," Jurnal Ilmiah Sekolah Dasar, vol. 3, no. 4, p. 545, 2019, [Online]. Available: https://ejournal.undiksha.ac.id/index.php/JISD/article/view/22311.

[14] A. Zakelj, "Procesi učenja z vidika učnih težav učencev pri matematiki," Revija za Elementarno Izobrazevanje, vol. 7, no. 2, pp. 5-22, 2014, [Online]. Available: https://www.proquest.com/docview/1544367789/BC85C06B00834E0APQ/3.

[15] P. Astuti, A. Mumpuni, and B. A. Pranoto, "Pengaruh Minat Dan Kemampuan Membaca Peserta Didik Dalam Memahami Teks Bacaan," Jurnal KONTEKSTUAL, vol. 01, no. 1, pp. 26-32, 2019, [Online]. Available: http://jurnal.umus.ac.id/index.php/kontekstual/article/view/55.

[16] A. Fatahillah, Y. F. Wati, and Susanto, "Analisis Kesalahan Siswa dalam Menyelesaikan Soal Cerita Matematika berdasarkan Tahapan Newman beserta Bentuk Scaffolding yang diberikan," Kadikma, vol. 8, no. 1, pp. 40-51, 2017, [Online]. Available: https://jurnal.unej.ac.id/index.php/kadikma/article/view/5229.

[17] E. Zakiyah, T. Handayani, and F. A. Sofyan, "Analisis Kesulitan Belajar Matematika Materi Operasi Hitung Campuran Siswa Kelas IV di MI Hijriyah II Palembang," AlAdzka: Jurnal Ilmiah Pendidikan Guru Madrasah Ibtidaiyah, vol. 9, no. 1, p. 41, 2019, [Online]. Available: https://jurnal.uin-antasari.ac.id/index.php/adzka/article/view/3006. 